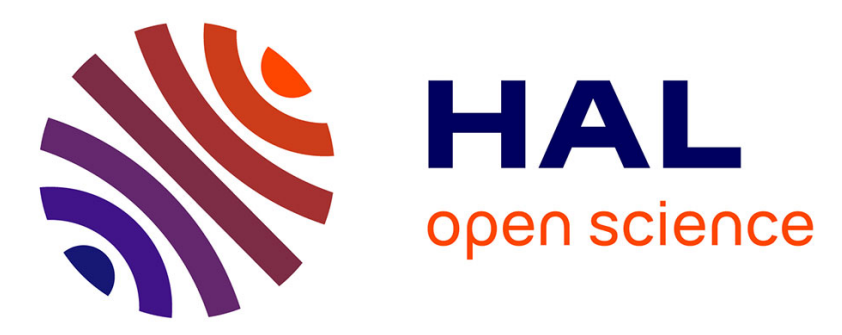

\title{
Biocompatibility study of two diblock copolymeric nanoparticles for biomedical applications by in vitro toxicity testing.
}

Felipe Goni-De-Cerio, Valentina Mariani, Dror Cohen, Lea Madi, Julie Thevenot, Hugo Oliveira, Chiara Uboldi, Guido Giudetti, Rosella Coradeghini, Elisabeth Garanger, et al.

\section{To cite this version:}

Felipe Goni-De-Cerio, Valentina Mariani, Dror Cohen, Lea Madi, Julie Thevenot, et al.. Biocompatibility study of two diblock copolymeric nanoparticles for biomedical applications by in vitro toxicity testing.. Journal of Nanoparticle Research, 2013, 15, 10.1007/s11051-013-2036-0 . hal-02353905

\section{HAL Id: hal-02353905 https://hal.science/hal-02353905}

Submitted on 7 Nov 2019

HAL is a multi-disciplinary open access archive for the deposit and dissemination of scientific research documents, whether they are published or not. The documents may come from teaching and research institutions in France or abroad, or from public or private research centers.
L'archive ouverte pluridisciplinaire HAL, est destinée au dépôt et à la diffusion de documents scientifiques de niveau recherche, publiés ou non, émanant des établissements d'enseignement et de recherche français ou étrangers, des laboratoires publics ou privés. 


\title{
Biocompatibility study of two diblock copolymeric nanoparticles for biomedical applications by in vitro toxicity testing
}

\author{
Felipe Goñi-de-Cerio • Valentina Mariani • Dror Cohen • Lea Madi • \\ Julie Thevenot $\cdot$ Hugo Oliveira $\cdot$ Chiara Uboldi - Guido Giudetti · \\ Rosella Coradeghini • Elisabeth Garanger · François Rossi - Meital Portugal-Cohen • \\ Miriam Oron • Rafi Korenstein - Sébastien Lecommandoux • Jessica Ponti • \\ Blanca Suárez-Merino $\cdot$ Pedro Heredia
}

Received: 11 June 2013/Accepted: 3 October 2013/Published online: 17 October 2013

\begin{abstract}
Drugs used for chemotherapy normally carry out adverse, undesired effects. Nanotechnology brings about new horizons to tackle cancer disease with a different strategy. One of the most promising approaches is the use of nanocarriers to transport active drugs. These nanocarriers need to have special properties to avoid immune responses and toxicity, and it is critical to study these effects. Nanocarriers
\end{abstract}

Felipe Goñi-de-Cerio and Valentina Mariani have contributed equally.

Electronic supplementary material The online version of this article (doi:10.1007/s11051-013-2036-0) contains supplementary material, which is available to authorized users.

F. Goñi-de-Cerio · B. Suárez-Merino · P. Heredia $(\bowtie)$ GAIKER Technology Centre, Parque Tecnológico de Zamudio Ed 202, 48170 Vizcaya, Spain

e-mail: heredia@gaiker.es

V. Mariani - C. Uboldi - G. Giudetti - R. Coradeghini ·

F. Rossi · J. Ponti

Nanobiosciences Unit, Institute for Health and Consumer Protection, Joint Research Centre, European Commission, Via E. Fermi 2749, 21027 Ispra, VA, Italy

D. Cohen · M. Portugal-Cohen · M. Oron

AHAVA, Dead Sea Laboratories, Lod, Israel

D. Cohen

The Dead Sea Laboratory for Biochemistry and Biotechnology of the Skin, Dead Sea and Arava Science Center, Ein-Gedi, Israel may have different nature, but polypeptide-based copolymers have attracted considerable attention for their biocompatibility, controlled and slow biodegradability as well as low toxicity. Little has been done regarding specific nanocarriers toxicity. In this study, we performed a thorough toxicological study of two different block copolymer nanoparticles (NPs); poly(trimethylene carbonate)-block-poly(L-glutamic acid) (PTMC- $b-\mathrm{PGA}$ ) and poly(ethylene glycol)block-poly $(\gamma$-benzyl-L-glutamate) (PEG- $b$-PBLG) with sizes between 113 and $131 \mathrm{~nm}$. Low bloodserum-protein interaction was observed. Moreover, general toxicity assays and other endpoints (apoptosis or necrosis) showed good biocompatibility for both NPs. Reactive oxygen species increased in only two

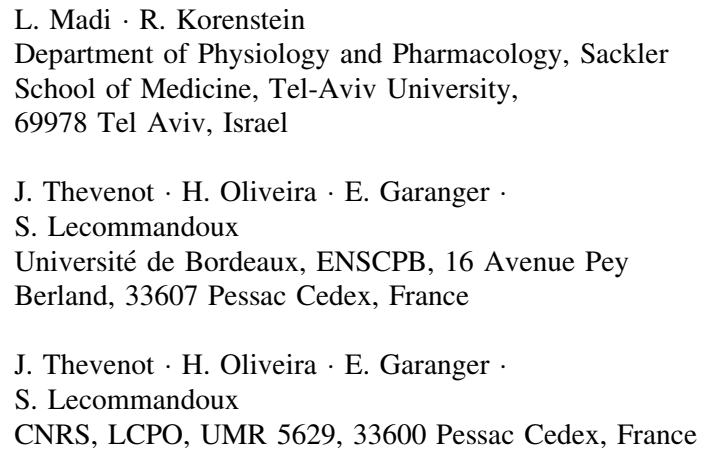


cell lines (HepG2 and TK6) in the presence of PTMC$b$-PGA. Cytokine production study showed cytokine induction only in one cell line (A549). We also performed the same assays on human skin organ culture before and after UVB light treatment, with a moderate toxicity after treatment independent of NPs presence or absence. Interleukin 1 induction was also observed due to the combined effect of PEG- $b-$ PBLG and UVB light irradiation. Future in vivo studies for biocompatibility and toxicity will provide more valuable information, but, so far, the findings presented here suggest the possibility of using these two NPs as nanocarriers for nanomedical applications, always taking into account the application procedure and the way in which they are implemented.

Keywords Amphiphilic copolymers .

Nanoparticles $\cdot$ In vitro toxicity $\cdot$ Cancer

therapy $\cdot$ Nanoparticles toxicity $\cdot$ Biomedicine

\section{Introduction}

Solid tumours account for more than $85 \%$ of cancer mortality. Chemotherapeutic drugs are often the selected treatment for cancer, but tumour structure and blood flow could determine poor penetration and limited distribution of these drugs, like it was demonstrated for doxorubicin (Lankelma et al. 1999). Nevertheless, the use of this therapeutic approach reckons with drug resistance and severe side effects due to non-selective cytotoxicity. One of the most promising approaches used to dodge these problems is to use nanosized carriers to deliver a chemotherapeutic drug deeply into the tumour (Upadhyay et al. 2009). These include natural vectors (protein carriers, viral vectors for gene therapy), pseudo-synthetic vectors (polymer-antibody hybrids, polymer-protein conjugates and antibody-targeted liposomes) and synthetic vectors (polymer-drug conjugates, polymer micelles, polymer-based nanoparticles, NPs; Chiellini et al. 2006, 2007). Within the synthetic vectors, polypeptide-based block copolymers have attracted considerable interest for their high biocompatibility, low and controlled degradability (Kricheldorf 2006) and complex and precise secondary conformations (Carlsen and Lecommandoux 2009) making them highly promising in biomedical applications (Arimura et al. 2005; Duncan et al. 2006; Oh et al. 1999; Mandal and
Chatterjee 2007). Amphiphilic diblock copolymers are made of a hydrophobic block that will constitute the inner core of the nano-assemblies, acting as a drug reservoir, and a hydrophilic block that forms the hydrated outer shell, which impedes uptake by the reticuloendothelial system (Jeong et al. 2004; Dong et al. 2004).

Lecommandoux's group recently demonstrated that a block copolymer poly(trimethylene carbonate)block-poly(L-glutamic acid) (PTMC-b-PGA) is able to form stable NPs in water (Sanson et al. 2010a, b). Moreover, they presented a successful method to load high doxorubicin doses in these NPs, strongly supporting the interest of developing PTMC- $b$-PGA NPs as carrier for the controlled delivery of chemotherapeutic drugs ( $\mathrm{Li}$ 2002; Li et al. 2008). Another promising polypeptide-based block copolymer for drug encapsulation is poly(ethylene glycol)-blockpoly $(\gamma$-benzyl-L-glutamate), PEG- $b$-PBLG (Jeong et al. 1999). The hydrophilic blocks of the two aforementioned block copolymers, PGA and PEG, are considered to be non-toxic at the dose required for drug carriers and prevents interactions with cells and proteins (Jeong et al. 2005; Vega-Villa et al. 2008). Nevertheless, studies on the potential toxicity of the two complete block copolymers are missing.

In the present study, morphology and physicochemical properties of both PTMC- $b$-PGA and PEG$b-\mathrm{PBLG}$ have been investigated to characterize the prepared NPs. Likewise, the NPs were carefully characterized for their biocompatibility using selected in vitro toxicity tests, specific for the evaluation of the cytotoxicity, apoptosis-necrosis induction, reactive oxygen species (ROS) detection and cytokine production. These assays were used on cell lines, representing potential target organs such as lung, intestine, skin, kidney and liver, in which it is described that NPs could accumulate and interact (Curtis et al. 2006; Lanone and Boczkowski 2006). In the literature there are not many examples of studies conducted to analyse the toxicity of nanocarriers per se ( $\mathrm{Li}$ et al. 2012). Furthermore, a toxic reaction against nanocarriers can be built on the knowledge of adverse reactions of cells model against NPs (Nishiyama and Kataoka 2006; Satchi-Fainaro et al. 2006).

To determine the in vitro toxicological profile induced by PTMC- $b-$ PGA and PEG- $b-\mathrm{PBLG}$, in this study we have investigated their potential cytotoxicity on at least seven cell lines from several organs and on 
human skin organ culture (HSOC) by Alamar Blue $(\mathrm{AB})$ and colony forming efficiency (CFE) assays as well as the induction of apoptosis and oxidative stress by flow cytometry analysis. Moreover, cytokine production was also investigated by sandwich enzyme-linked immunoassays test, in order to measure cytokine release.

\section{Methods}

NPs synthesis and characterisation

$\mathrm{PTMC}_{25}-b-\mathrm{PGA}_{12} \quad(2,550-b-1,540 \mathrm{~g} / \mathrm{mol}) \quad$ and $\mathrm{PEG}_{45}-b-\mathrm{PBLG}_{13}(2,000-b-2,850 \mathrm{~g} / \mathrm{mol})$ were synthesized as previously described and with minor modifications (Sanson et al. 2010a, b; Martinez Barbosa et al. 2007).

NPs were obtained from amphiphilic block copolymers by solvent assisted self-assembly using the nanoprecipitation method (Sanson et al. 2011).

$Z$-average hydrodynamic diameter $\left(D_{\mathrm{H}}\right)$, polydispersity index (PDI) and size distribution of NPs in water were evaluated via dynamic light scattering (DLS) using Milli-Q water. The DLS and surface charge (obtained by capillary electrophoresis) measurements were performed on $1 \mathrm{ml}$ sample volume on a Zetasizer Nano Zs (Malvern Instruments) at $25^{\circ} \mathrm{C}$, following the protocols indicated by ISO 13321:1996. The data acquisition was carried out using the automatic adjustment of position, attenuation and measurement time. Mean values of $D_{\mathrm{H}}$ and PDI (average on three measures) were obtained from the ratio of the second order cumulate divided by the square of the first order one. Only intensity distribution data were considered for the analysis. Graphs were obtained by averaging three measurements per batch using Malvern's proprietary software.

Morphologies of stock suspensions were obtained by transmission electron microscopy analysis (TEM; Hitachi $\mathrm{H} 7650$ microscope working at $80 \mathrm{kV}$ equipped with a GATAN ORIUS SC1100 11 Megapixel camera, imaging facility provided by Bordeaux Imaging Center, Bordeaux University, France). Samples were coated on copper grids (200 mesh coated with carbon or carbon/Formvar ${ }^{\mathrm{TM}}$ ) by spraying $1 \mathrm{~g} / \mathrm{l}$ suspensions of particles using a homemade spraying tool. After complete drying, samples were stained with a $1 \% \mathrm{w} / \mathrm{v}$ uranyl acetate (Agar Scientific) solution in water.

Interaction of nanocarriers with cell culture medium and blood serum

Interaction of nanocarriers with cell culture medium was carried out using MEM cell culture medium dispersions prepared at $0.5 \mathrm{mg} / \mathrm{ml} \mathrm{NP}$ final concentration and incubated $1 \mathrm{~h}$ at $37^{\circ} \mathrm{C}$. Measurements were done at increasing concentrations $(0,0.1,1$ and $10 \% \mathrm{v} / \mathrm{v}$ ) of added foetal bovine serum (FBS, Gibco) to assess eventual serum protein concentration effects on polydispersity and measured size. DLS measurements were performed in the same conditions described previously for three independent experiments and three replicates for each experimental point.

The interaction of NPs with human plasma serum assay was performed according to the protocols established at Nanotechnology Characterization Laboratory. Samples were obtained by Dr. Miguel Angel Vesga from Centro Vasco de Transfusiones, Galdakao Hospital. The Basque Biobank for Research-OEHUN (www.biobancovasco.org) processed and released the samples following standard operation procedures with appropriate ethical approval. Plasma was incubated with $1 \mathrm{mg} / \mathrm{ml}$ of PTMC- $b-$ PGA or PEG- $b-$ PBLG for $30 \mathrm{~min}$ at $37^{\circ} \mathrm{C}$. Then, plasma-NP suspension was spun twice to remove any trace of unbound proteins and to obtain the NPs attached to proteins. Pellet was then resuspended in 2D-PAGE loading buffer (Biorad) to detach NPs from proteins and spun again. Supernatant (protein fraction) was recovered and the protein amount was quantified using EZQ Protein Quantitation kit (Invitrogen). Protein sample was later electrofocused (first dimension) using IPG strips $\mathrm{pH}$ 3-10 (Biorad). IPG strips were later equilibrated and electrophoresed in a $17 \mathrm{~cm}$ long, $1.5 \mathrm{~mm}$ thick and $12 \%$ polyacrylamide gel (second dimension). Proteins were stained with SYPRO Ruby (Invitrogen) and imaged under VersaDoc image analyser (Biorad). Protein identification was performed using MALDI-TOF.

Cell and skin model culture conditions

Human keratinocyte cells (HaCaT) were originally supplied by the German Cancer Research Center (Germany), human alveolar cells (A549), human 
intestinal cells (Caco-2), dog kidney cells (MDCK), hepatocellular carcinoma cells (HepG2) and human lymphoblast cells (TK6) were originally purchased from the American Type Culture Collection. BALB/ 3T3 mouse fibroblasts were purchased from Hatano Research Institute (Japan). The cell lines were maintained in complete culture mediums according to the suppliers' guidelines and were routinely grown as a monolayer in tissue culture grade flasks. When cells exceeded $70 \%$ confluence (but less than $90 \%$ ), they were sub-cultured on new culture flasks. All the cell cultures were maintained in standard cell culture conditions $\left(37{ }^{\circ} \mathrm{C}, 5 \% \mathrm{CO}_{2}\right.$ and $95 \%$ humidity). For HSOC model, skin pieces of breast or abdomen were obtained with informed consent from healthy, 35-50 year-old women undergoing plastic surgery. Up to $6 \mathrm{~h}$ from the surgery the skin was cut to a $0.16 \mathrm{~cm}^{2}$ pieces, and samples were placed with dermis facing down and epidermis facing up in culture plates containing DMEM medium with antibiotics (1\% penicillin-streptomycin). Cultures were incubated for $24 \mathrm{~h}$, at $37{ }^{\circ} \mathrm{C}$ under $5 \% \mathrm{CO}_{2}$ for recovery.

\section{Cytotoxicity assays}

Cytotoxicity was assessed by $\mathrm{AB}$ and $\mathrm{CFE}$ on $\mathrm{HaCaT}$, A549, Caco-2, MDCK, HepG2 and BALB/3T3 cell lines. AB was also used for testing of TK6 cell line and HSOC model. Necrosis/apoptosis induction, cytokine production and oxidative stress determination studies were carried out on all the six-seven cell lines and on HSOC model.

The selected exposure times were $24 / 72 \mathrm{~h}$ and the concentrations tested were 0.1 and/or $0.5 \mathrm{mg} / \mathrm{ml}$ of PTMC- $b-$ PGA and PEG- $b$-PBLG suspensions for cytotoxicity assessment.

\section{$A B$ assay}

$\mathrm{AB}$ assay was used to assess cytotoxicity induced by PTMC- $b-$ PGA and PEG- $b-$ PBLG dispersions on seven cell lines and HSOC model after $24 \mathrm{~h}$ of exposure to 0.1 and $0.5 \mathrm{mg} / \mathrm{ml}$. Cells were seeded in 96 well plates (at a density of 5,000-10,000 depending on the cell line) to reach 70-80\% confluence at the end of the assay, at least six replicates for each treatment were tested. The day after seeding, cells were exposed to 0.1 and $0.5 \mathrm{mg} / \mathrm{ml}$ of PTMC- $b-$ PGA and PEG- $b$ PBLG suspensions for $24 \mathrm{~h}$. Each experiment included a negative control (untreated cells in culture medium) and a positive control (treated with sodium dodecyl sulphate). At the end of the exposure period, each well was supplemented with $\mathrm{AB}$ solution (Invitrogen). After $4 \mathrm{~h}$ incubation under standard cell culture conditions, data were acquired by means of a spectrophotometer measuring the absorbance at $570 \mathrm{~nm}$. Afterwards, all experiments were carried out in quadruplicate and expressed as the percentage of $\mathrm{AB}$ reduction in the test wells compared to the untreated controls.

For the HSOC model, after 24 and $72 \mathrm{~h}$ of incubation with the NPs, the whole human skin culture was placed with $300 \mu \mathrm{l}$ of DMEM and $0.01 \mathrm{mg} / \mathrm{ml}$ of Resazurin. The tissue was incubated for $1 \mathrm{~h}$. Data were acquired by a spectrophotometer measuring the absorbance at $570 \mathrm{~nm}$.

\section{Colony forming efficiency}

Assays were performed according to Ponti et al. (2010). Cells were seeded in $60 \times 15 \mathrm{~mm}$ petri dishes at a density of 200-300 cells/dish in $3 \mathrm{ml}$ complete culture medium at least in three replicates for each treatment. After $24 \mathrm{~h}$, PTMC- $b-\mathrm{PGA}$ and PEG- $b$-PBLG suspensions were directly added to the cell culture to obtain the appropriate final concentration of $0.1 \mathrm{mg} / \mathrm{ml}$. After 24 and $72 \mathrm{~h}$ of exposure, the medium was changed with complete fresh culture medium that was renewed twice weekly. After 7 days, cells were fixed for $20 \mathrm{~min}$ with $3.7 \%$ formaldehyde solution in PBS. Dishes were stained for $30 \mathrm{~min}$ with $4 \% \mathrm{v} / \mathrm{v}$ Giemsa solution (Sigma) in ultrapure water. Colonies were manually scored under a stereomicroscope. Each experiment included a negative control and a positive control (cells exposed to sodium chromate $1,000 \mu \mathrm{M})$. The corresponding standard error mean was calculated for three independent experiments and three replicates for each experimental point.

\section{Apoptosis/necrosis induction}

Potential apoptosis and necrosis induction were studied in the cell lines using Annexin V conjugated with Alexa Fluor 488 (Molecular Probes) and propidium iodide (PI; Sigma-Aldrich) fluorochromes by flow cytometry, to measure early apoptotic event and necrosis, respectively, after exposure to 0.1 and 
$0.5 \mathrm{mg} / \mathrm{ml}$ of PTMC- $b-$ PGA and PEG- $b-$ PBLG suspensions for 24 and $72 \mathrm{~h}$. Apoptosis studies were also carried out in HSOC models by Ac-DEVD-AMC, a fluorogenic substrate specific of caspase 3 (Calbiochem) after exposure to 0.1 and $0.5 \mathrm{mg} / \mathrm{ml}$ of PTMC$b$-PGA and PEG- $b-$ PBLG suspensions for $24 \mathrm{~h}$.

HaCaT, Caco-2, A549, MDCK, HepG2 and BALB/ $3 \mathrm{~T} 3$ cells were seeded in 24 well plates at a density of 100,000 cells/well for $24 \mathrm{~h}$ and 50,000 cells/well for $72 \mathrm{~h}$ in all cell lines in complete culture medium and exposed to NPs. 24 and $72 \mathrm{~h}$ after the exposure of cells to NPs $(0.1$ and $0.5 \mathrm{mg} / \mathrm{ml}$ of PTMC- $b-\mathrm{PGA}$ and PEG- $b-\mathrm{PBLG}), 5 \mu \mathrm{l}$ of the Annexin V conjugates were added to each $100 \mu \mathrm{l}$ of cell suspension (minimum of 10,000 cell/100 $\mu \mathrm{l}$ ) and incubated at room temperature for $15 \mathrm{~min}$. After incubation, cells were washed and submitted to flow cytometry acquisition. Without delay, the stained cells were contrasted immediately with PI $(5 \mu \mathrm{g} / \mathrm{ml})$ to detect necrotic cells and analyzed by Beckman Coulter FC500 MPL flow cytometer. As positive control, cells were incubated with $1 \mu \mathrm{M}$ of doxorubicin hydrochloride (Discovery Fine Chemicals, Ltd.) for $24 \mathrm{~h}$. Three independent experiments and at least three replicates for each experimental point were carried out. Each experiment included a negative control (untreated cells) and a positive control. Results were expressed as the percentage of Annexin V and PI positive cells.

For the HSOC model, after $24 \mathrm{~h}$ of incubation with the NPs, the skin samples were incubated for $1 \mathrm{~min}$ in PBS at $56{ }^{\circ} \mathrm{C}$, and the epidermis was separated from the dermis with a scalpel. Epidermal sheets were incubated in PBS containing $2.5 \mu \mathrm{M}$ Ac-DEVD-AMC with $0.02 \%$ Triton X-100, $10 \mathrm{mM}$ dithiothreitol and $20 \mathrm{mM}$ Tris $\mathrm{pH} 7.4$, at $37^{\circ} \mathrm{C}$. Fluorescence was measured at $355 / 460 \mathrm{~nm}$ on a fluorometer (Thermo Scientific), and the activity was calculated in the linear range. Three independent experiments and at least three replicates for each experimental point were carried out. Each experiment included a negative control.

\section{Oxidative stress determination}

Potential oxidative stress induced by PTMC- $b-\mathrm{PGA}$ and PEG- $b-$ PBLG suspensions was studied on all the cell lines after exposure to $0.5 \mathrm{mg} / \mathrm{ml}$ of NPs by dichlorodihydrofluorescein diacetate $\left(\mathrm{H}_{2} \mathrm{DCF}-\mathrm{DA}\right.$, Invitrogen), used to determine changes in ROS activity. It permeates the cell membrane and accumulates mostly in the cytosol following deacetylation by esterases to dichlorodihydrofluorescein. This nonfluorescent product is converted by ROS into dichlorofluorescein (DCF; $E_{\mathrm{x}}=488 \mathrm{~nm} ; E_{\mathrm{m}}=525 \mathrm{~nm}$ ). Cells were seeded in six well plates at a non-confluent cell density $\left(10^{5}\right.$ cell $\left./ \mathrm{ml}\right)$, after $24 \mathrm{~h}$ the medium was removed and the treatment medium containing $0.5 \mathrm{mg} / \mathrm{ml}$ PTMC- $b$-PGA or PEG- $b-$ PBLG suspensions was added for an exposure time of $1.5 \mathrm{~h}$. Then treatment suspensions were replaced with carboxy$\mathrm{H}_{2}$ DCF-DA $(10 \mu \mathrm{M})$ by adding it to the free-serum medium. After incubation of $0.5 \mathrm{~h}$, cells were washed and the intracellular fluorescence of DCF was measured by flow cytometry (FACSCalibur). Three independent experiments and at least three replicates for each experimental point were carried out. Each experiment included a negative control (untreated cells) and a positive control (tert-butyl hydroperoxide $0.5 \mathrm{mM}$ ). Results were expressed as a geometrical mean relative to control.

Cytokine production determination

Cytokine production induced by PTMC- $b$-PGA and PEG- $b-$ PBLG suspensions was studied on six cell lines and HSOC model cultures.

Cells and HSOC model were exposed to $0.5 \mathrm{mg} / \mathrm{ml}$ of NPs for $24 \mathrm{~h}$. In addition, controlled cytokine production was induced on HSOC cultures irradiating them at a dose of $500 \mathrm{~mJ} / \mathrm{cm}^{2}$ (312 nm). Immediately after irradiation PTMC- $b$-PGA and PEG- $b-\mathrm{PBLG}$ were added to the medium to reach $0.5 \mathrm{mg} / \mathrm{ml}$ concentration for $24 \mathrm{~h}$ of incubation. Each experiment included a negative control. After incubation, cytokine concentrations (TNF $\alpha$, interleukin [IL] 1 $\alpha$, IL-6, IL-8) were determined in culture media by sandwich enzyme-linked immunoassays, using ELISA high sensitivity kits (Biolegend, Inc.). In brief, a polystyrene microtiter plate was coated with a cytokine-specific, monoclonal antibody and blocked with $1 \%$ bovine serum albumin. Samples were incubated with the immobilized antibody, unbound materials were washed off and a second antibody, directed at a different epitope of the same antigen, was added and incubated. After washing away unbound materials, a horseradish peroxidase-linked antibody was used to reveal the immobilized complexes. Recombinant cytokines were used as internal standards. The corresponding standard error mean was calculated for three 

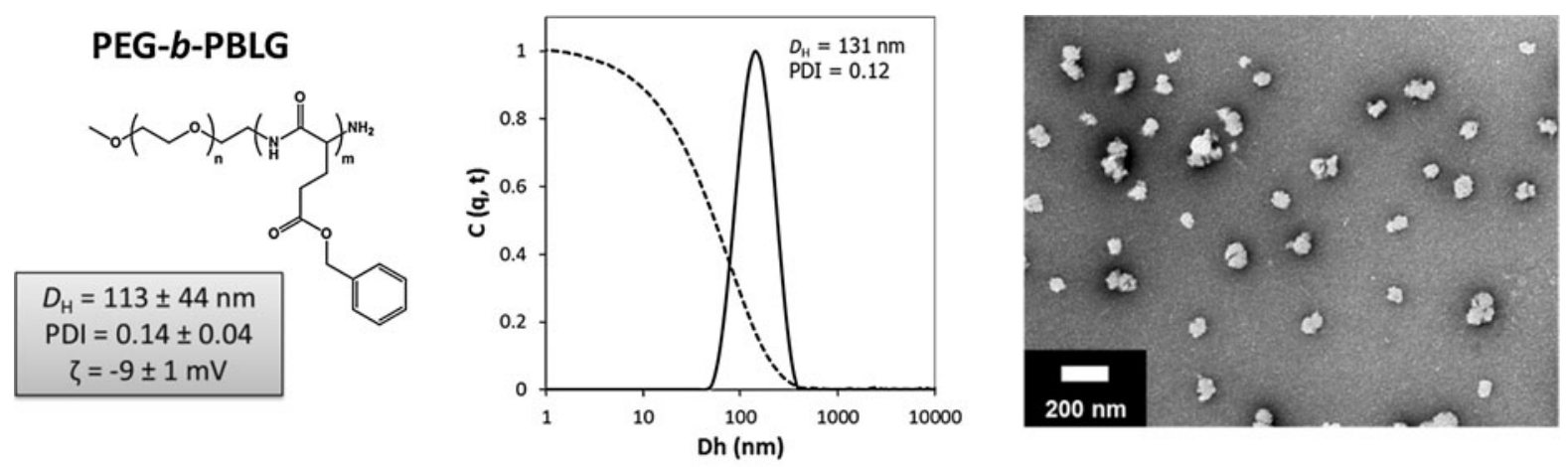

\section{PTMC- $b$-PGA}
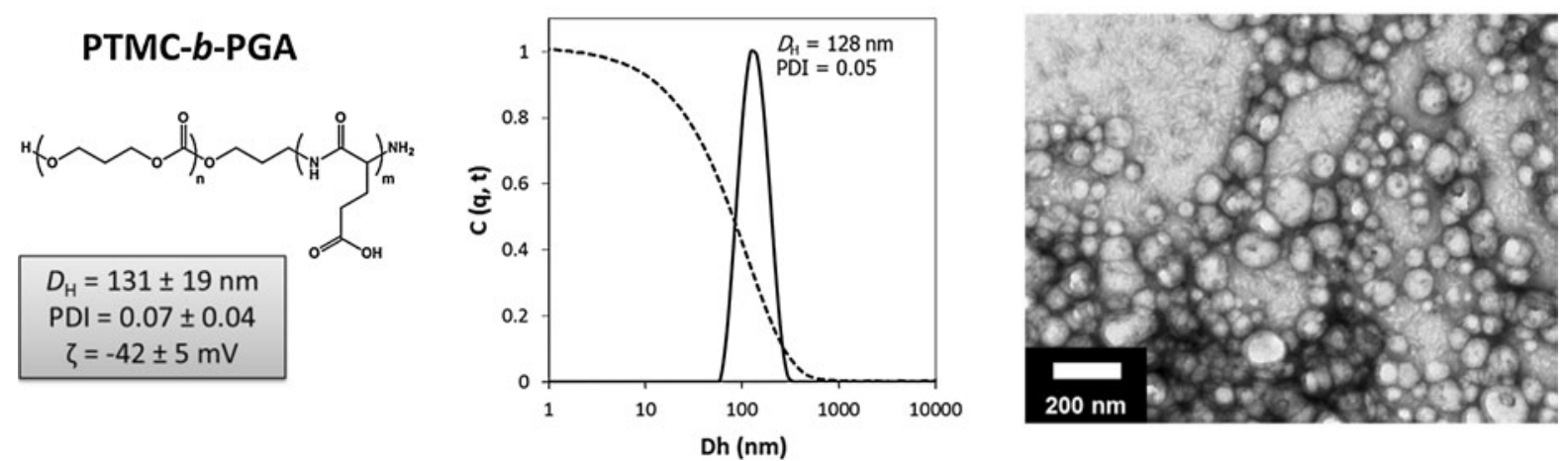

Fig. 1 Chemical structure of the two amphiphilic block copolymers, PEG- $b$-PBLG and PTMC- $b-\mathrm{PGA}$ and characteristics of the particles prepared for this study. Left column chemical structure and average hydrodynamic diameter $\left(D_{\mathrm{H}}\right)$, polydispersity index (PDI) and $\zeta$ for $n=10$ (average on different particle

independent experiments and three replicates for each experimental point compared to the untreated controls.

\section{Statistical analysis}

Results were contrasted with a Levene test to confirm the homogeneity of variance between the different groups and Kolmogorov-Smirnoff test for normality. Unpaired $t$ test and one factor analysis of variance (ANOVA) with Bonferroni-Dunn's correction were performed to assess differences in all studied parameters: $p<0.005$ has been considered as statistically significant $(*)$.

\section{Results}

NP synthesis and characterisation

PTMC- $b$-PGA and PEG- $b-$ PBLG were analysed by TEM, and the images obtained showed a vesicular batches) in water. Middle column typical relaxation curve and size distribution obtained by DLS analysis. Right column TEM picture showing the morphology of PEG- $b$-PBLG (top) and PTMC- $b$-PGA (bottom) particles

morphology for PTMC- $b$-PGA and a particulate morphology for PEG- $b-\mathrm{PBLG}$ (Fig. 1). The mean $D_{\mathrm{H}}$ of the particles' stock solutions measured by DLS were $113 \pm 44 \mathrm{~nm}$ for PEG- $b-$ PBLG and $131 \pm 19 \mathrm{~nm}$ for PTMC- $b$-PGA (Fig. 1) of 10 different batches prepared on this study. Zeta potential

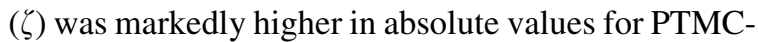
$b$-PGA $(-42 \mathrm{mV})$ than for PEG- $b-$ PBLG $(-9 \mathrm{mV})$, indicating a potential higher colloidal stability in water of the former NP.

Interaction of nanocarriers with cell culture medium and blood serum

The values for PDI and $D_{\mathrm{H}}$ are shown for a single NP batch in Table 1. There was a very small tendency to PDI increase when increasing serum concentration in the conditions of this study. This effect was evident when $10 \%$ serum was used. Both the PTMC- $b-\mathrm{PGA}$ and PEG- $b-$ PBLG PDI increased notably, from $0.15 \pm 0.01$ to $0.3 \pm 0.03$ and from $0.07 \pm 0.01$ to 
Table 1 Example of DLS study of one batch of PEG- $b$-PBLG and PTMC- $b$-PGA NPs in cell culture medium (MEM) untreated and with increasing concentrations of serum $(0.1,1$ and $10 \%[\mathrm{v} / \mathrm{v}])$

\begin{tabular}{llr}
\hline FBS $(\%)$ & PDI \pm SD & $D_{\mathrm{H}}(\mathrm{nm}) \pm \mathrm{SD}$ \\
\hline PEG- $b-$ PBLG & & \\
0 & $0.07 \pm 0.01$ & $94.88 \pm 1.13$ \\
0.1 & $0.08 \pm 0.02$ & $93.99 \pm 1.61$ \\
1 & $0.09 \pm 0.02$ & $95.39 \pm 0.09$ \\
10 & $0.17 \pm 0.01$ & $96.92 \pm 2.43$ \\
PTMC- $b-$ PGA & & \\
0 & $0.15 \pm 0.01$ & $98.44 \pm 3.73$ \\
0.1 & $0.16 \pm 0.01$ & $97.78 \pm 1.12$ \\
1 & $0.18 \pm 0.04$ & $102.30 \pm 3.33$ \\
10 & $0.30 \pm 0.03$ & $101.40 \pm 1.31$ \\
\hline
\end{tabular}

FBS foetal bovine serum, $P D I$ polydispersity index, $D_{H}$ hydrodynamic diameter

Table 2 Quantitation of blood proteins associated to PEG- $b-$ PBLG and PTMC- $b-$ PGA after treatment of blood serum with $1 \mathrm{mg} / \mathrm{ml}$ of each NP for $30 \mathrm{~min}$ at $37^{\circ} \mathrm{C}$

\begin{tabular}{|c|c|c|}
\hline & Protein $(\mu \mathrm{g} / \mathrm{ml}) \pm \mathrm{SD}$ & $\begin{array}{l}\text { Protein (\% of } \\
\text { control) }\end{array}$ \\
\hline PBS (solution) & $8.47 \times 10^{4} \pm 1.11 \times 10^{4}$ & 100 \\
\hline $\begin{array}{l}\text { PBS } \\
\text { (precipitate) }\end{array}$ & $5.52 \pm 0.87$ & 0.007 \\
\hline $\begin{array}{l}\text { PTMC- } b \text {-PGA } \\
(1 \mathrm{mg} / \mathrm{ml})\end{array}$ & $90.51 \pm 10.59$ & 0.107 \\
\hline PBS (solution) & $1.11 \cdot 10^{5} \pm 1.27 \cdot 10^{4}$ & 100 \\
\hline $\begin{array}{l}\text { PBS } \\
\text { (precipitate) }\end{array}$ & $9.93 \pm 1.95$ & 0.009 \\
\hline $\begin{array}{l}\text { PEG- } b-\text { PBLG } \\
(1 \mathrm{mg} / \mathrm{ml})\end{array}$ & $83.73 \pm 2.53$ & 0.075 \\
\hline
\end{tabular}

$0.17 \pm 0.01$, respectively, when $10 \%$ serum containing media was used. The overall fold change for both NPs was 2.00 for PTMC- $b-$ PGA and 2.43 for PEG- $b-$ PBLG.

The quantification analyses of the assays of NPs interaction with blood serum components are described in Table 2. The concentration of proteins in blood serum for different batches, measured in the conditions of this assay, was between 80 and $100 \mathrm{mg} / \mathrm{ml}$. The values for the control of precipitation carried out adding PBS to the blood serum instead of NPs were $5.52 \pm 0.87$ and $9.93 \pm 1.95 \mu \mathrm{g} / \mathrm{ml}$, representing less that $0.01 \%$ of the total protein value in each sample. The concentration values for precipitated proteins after treatment with both PTMC- $b-\mathrm{PGA}$ and PEG- $b-$ PBLG were $83.73 \pm 2.53$ and $90.51 \pm$ $10.59 \mu \mathrm{g} / \mathrm{ml}$, respectively. These values represent 0.107 and $0.075 \%$ of the total protein in plasma and were around ten times higher than the precipitated control (PBS), but significantly low compared to blood serum total protein concentration. After protein quantification, the pellet obtained was cleaned to remove NPs and subjected to 2D-PAGE analysis, according to the procedure already described. The most representative and abundant proteins identified by MALDITOF are shown in Table 3. Proteins corresponded to different families and routes like protein transport (apolipoproteins, mitoferrin-2) or immune response proteins (immunoglobulins, ficolin, etc.).

\section{Cytotoxicity assays in cell lines and HSOC model}

To detect the cytotoxicity of PTMC- $b-$ PGA and PEG$b$-PBLG, AB and CFE assays were performed. The $\mathrm{AB}$ assays results are shown in Fig. 2a: neither PTMC- $b-$ PGA nor PEG- $b-$ PBLG (named A and B respectively in all figures hereafter) showed any cytotoxicity at tested concentrations for each of the cell lines considered. Only a slight decrease in TK6 viability was shown at $0.5 \mathrm{mg} / \mathrm{ml}$ when cells were treated with PEG- $b$-PBLG, but it was not statistically significant.

Epidermal viability of HSOC models after treatment with either PTMC- $b$-PGA or PEG- $b$-PBLG was detected using $\mathrm{AB}$ assays at $24 \mathrm{~h}$ and $72 \mathrm{~h}$ following UVB irradiation (Fig. 2b). The results after $24 \mathrm{~h}$ of NP incubation showed that UVB irradiation induced a slight decrease in cell viability in all experimental groups, although this decrease was not statistically significant. UVB irradiation effect was significant at

Table 3 Proteins identified by MALDI-TOF after 2D-PAGE for precipitated blood serum fraction after treatment with either PTMC- $b-$ PGA or PEG- $b-$ PBLG at $1 \mathrm{mg} / \mathrm{ml}$

\begin{tabular}{ll}
\hline PTMC- $b-\mathrm{PGA}$ & PEG- $b-\mathrm{PBLG}$ \\
\hline Ig $\gamma-2, \gamma-3, \kappa, \mu$ & Keratin \\
Apolipoprotein A-1, & Apolipoprotein A-1, \\
A-4, E & A-4, E \\
Ficolin-3 & Ficolin-3 \\
Mitoferrin-2 & Fibrinogen $\beta$ chain \\
& Fibrinogen C \\
\hline
\end{tabular}


Fig. 2 Percentage of cell viability obtained in Alamar Blue cytotoxicity assays performed using A549, HepG2, MDCK, HaCaT, BALB/3T3, Caco-2 and TK6 cell lines as test systems at $24 \mathrm{~h} \mathrm{(a)} \mathrm{and}$ HSOC model (b) at 24 and $72 \mathrm{~h}$. Cells were treated with 0.1 and $0.5 \mathrm{mg} / \mathrm{ml}$ and HSOC model was treated with $0.5 \mathrm{mg} / \mathrm{ml}$ of PTMC$b$-PGA or PEG- $b-\mathrm{PBLG}$.

Values are expressed as the mean of $\%$ cell viability $\pm \mathrm{SD}$. One-factor analysis of variance (ANOVA) was performed
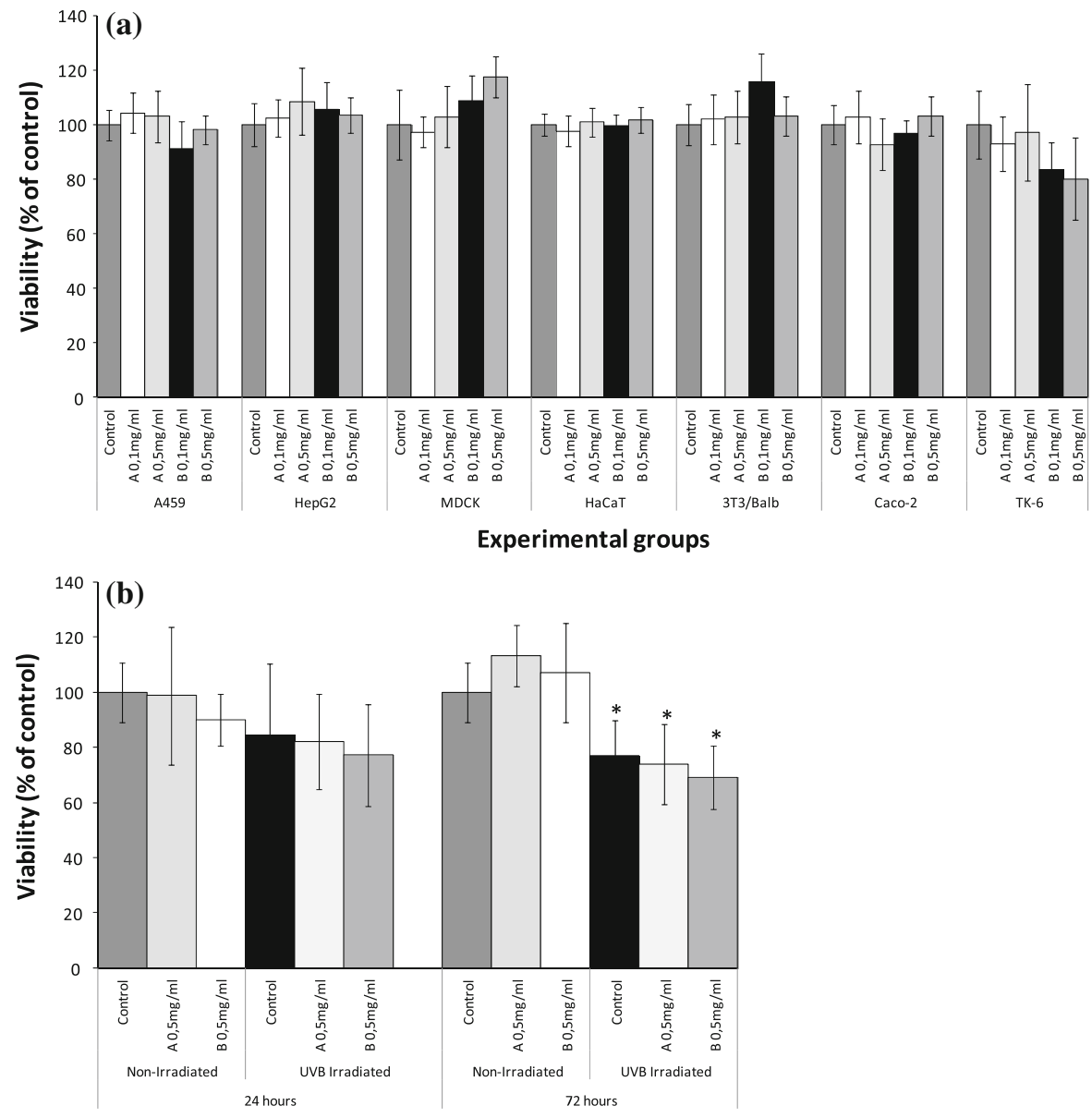

$72 \mathrm{~h}$, where a marked decrease in cell viability could be seen after UVB irradiation in all studied groups (untreated control group included). As there is no significant difference between irradiated NPs treated samples and irradiated untreated samples, the decrease in cell viability could only be associated to the effect of UVB irradiation.

To perform a non-colorimetric cytotoxicity study, CFE assays were carried out. In this study TK6 was not included, since it is a suspension cell line. Results confirmed no cytotoxicity in all studied cell lines for either 24 or 72 h (Fig. 3), in good agreement with the results of $\mathrm{AB}$. There was a small decrease in viability in $\mathrm{HaCaT}$ at $24 \mathrm{~h}$ when treated with PEG- $b-\mathrm{PBLG}$, but this effect could not be seen at $72 \mathrm{~h}$ and it was not statistically significant. At $72 \mathrm{~h}$, MDCK mortality slightly increased after incubation with PEG- $b-$ PBLG, but again, the reduction was not statistically significant.
Apoptosis/necrosis determination in cell lines

Cell viability associated to PTMC- $b$-PGA and PEG$b-$ PBLG treatment was also evaluated investigating apoptosis and necrosis endpoints at different times (Figs. 4, 5). Cells positive for Annexin V-Alexa Fluor and negative for PI were apoptotic, and PI positive cells were necrotic cells. Cells positive for membrane asymmetry study did not show a significant increase of apoptotic index, treated with either PEG- $b-\mathrm{PBLG}$ or PTMC- $b-$ PGA at 0.1 and $0.5 \mathrm{mg} / \mathrm{ml}$ as compared to untreated cultures after 24 and $72 \mathrm{~h}$ of NPs incubation. The values for apoptotic cells after NPs incubation for $24 \mathrm{~h}$ did not surpass $20 \%$ in any treatment, including control untreated cells with values between 7 and $17 \%$ depending on the cell type (Fig. 4a). In most of the cell lines studied there was a non-significant difference between control sample and treated samples, always below $5 \%$. Moreover, the same values 
Fig. 3 Percentage of cell viability obtained in colony forming efficiency assays (CFE) using A549, HepG2, MDCK, HaCaT, BALB/3T3 and Caco- 2 cell lines as test system. Cells were incubated with $0.1 \mathrm{mg} / \mathrm{ml}$ of either PTMC- $b-\mathrm{PGA}$ or PEG- $b$-PBLG for 24 or $72 \mathrm{~h}$. Values are expressed as the mean of $\%$ positive cells \pm SD. One-factor analysis of variance (ANOVA) was performed

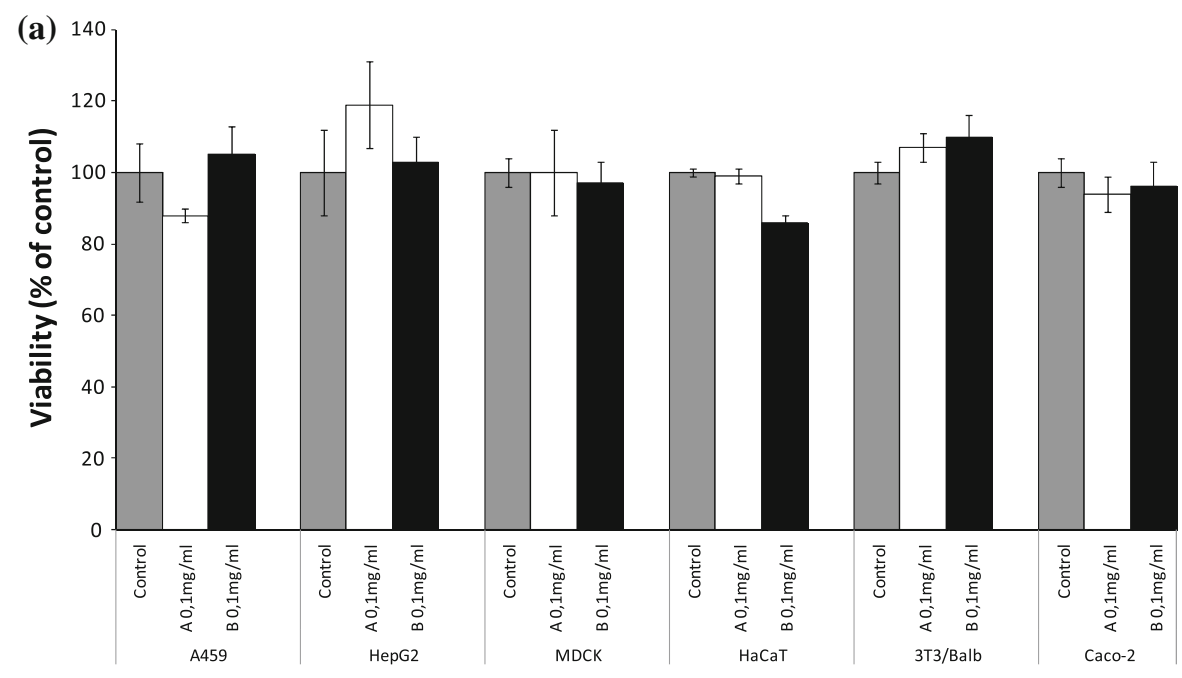

Experimental groups

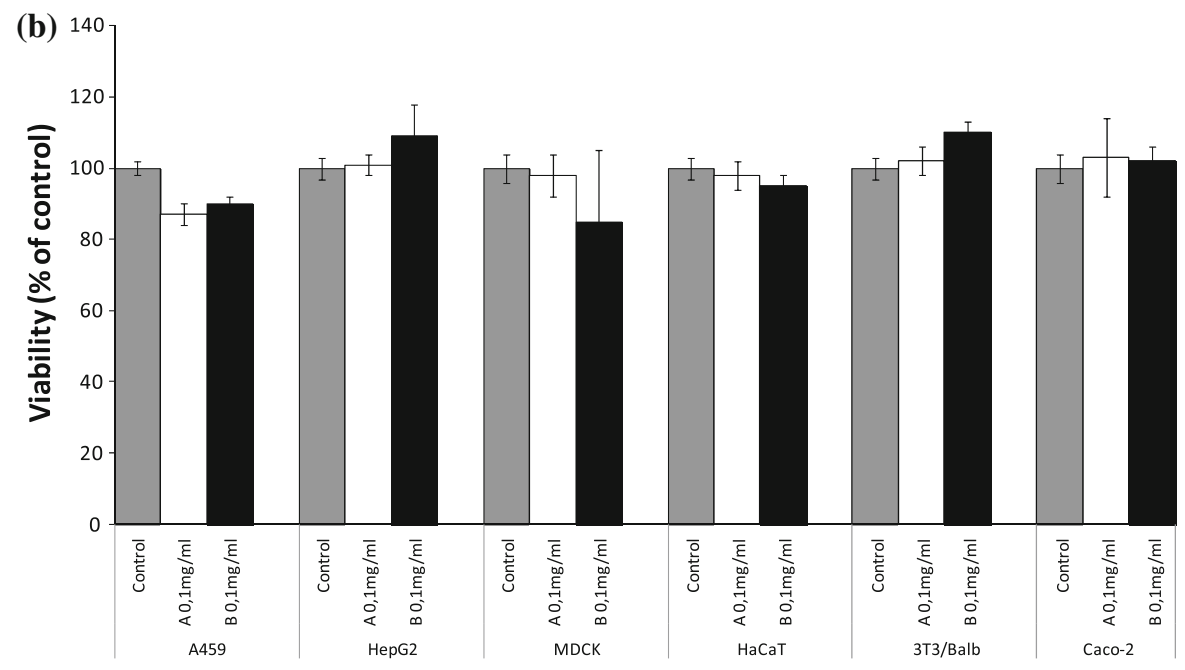

Experimental groups were observed regarding PI positive cells at $24 \mathrm{~h}$ (Fig. 4b). The positive cells for necrosis were always below $12 \%$ in all situations tested.

Likewise, cells positive for membrane asymmetry study at $72 \mathrm{~h}$ did not show a significant increase of apoptotic index, after treating cells with either PEG- $b-$ PBLG or PTMC- $b-$ PGA at 0.1 and $0.5 \mathrm{mg} / \mathrm{ml}$ as compared to untreated cultures (Fig. 5a). At the same time, the percentage of PI positive cells in NPs treated cultures also maintained similar values to those obtained for control cultures (Fig. 5b). Annexin $\mathrm{V}$ positive cells were below $25 \%$, and PI positive cells were below $14 \%$ in all cases. Thus, using
Annexin V, our study indicates that neither necrosis nor apoptosis index increase was detected in the employed cell cultures after 24 and $72 \mathrm{~h}$ concerning NP incubation.

Further analysis of apoptotic index in HSOC model (Fig. 6) was carried out using caspase 3 assays at $24 \mathrm{~h}$. Caspase 3 activity was markedly increased following UVB irradiation in all experimental groups, including control. In relation to non-irradiated control samples caspase 3 values obtained were 51-fold regarding untreated irradiated control and 25- and 28-fold regarding PTMC- $b-\mathrm{PGA}$ and PEG- $b-\mathrm{PBLG}$ NPs, respectively. In non-irradiated samples, both PTMC- 
Fig. 4 Percentage of Annexin V (a) and propidium iodide (b) positive cells analyzed by flow cytometry after $24 \mathrm{~h}$ of NPs exposure. Values are expressed as the mean of \% positive cells $\pm \mathrm{SD}$. Onefactor analysis of variance (ANOVA) was performed

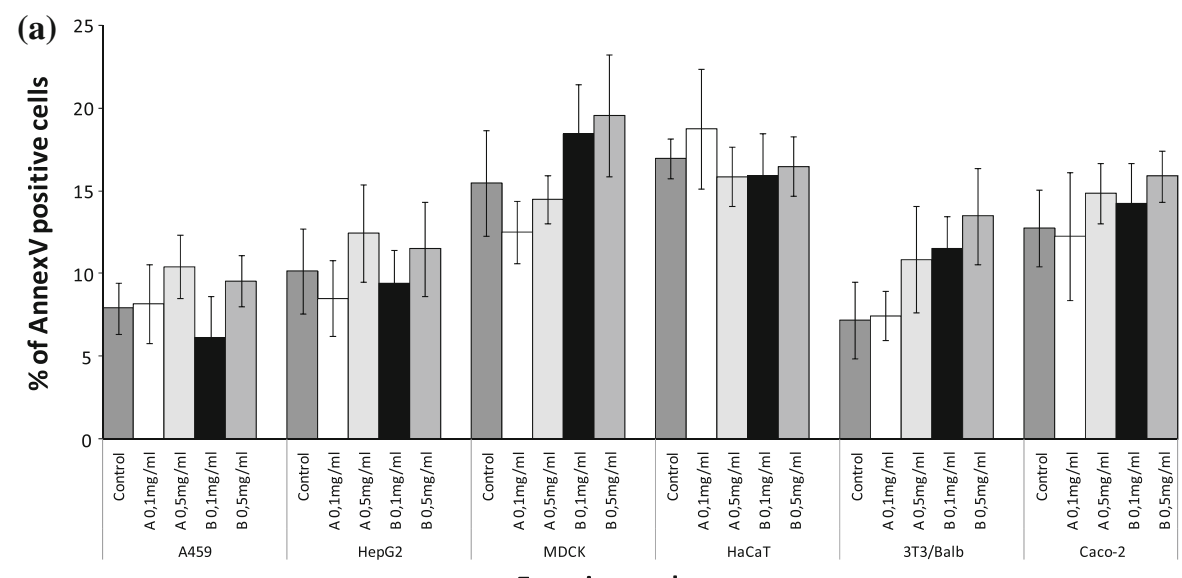

Experimental groups

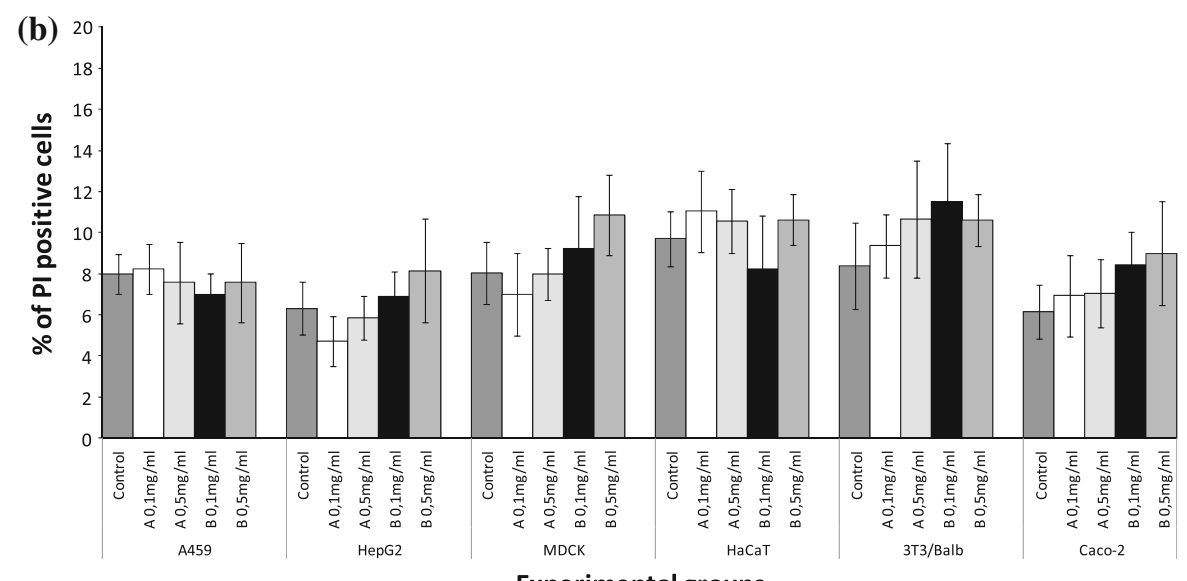

$b$-PGA and PEG- $b$-PBLG NPs increased slightly caspase 3 activity (1.9- and 1.6-fold, respectively), compared to control samples.

\section{Oxidative stress determination}

Even if toxicity was not observed for PTMC- $b-\mathrm{PGA}$ or PEG- $b-\mathrm{PBLG}$ on all the tested cell lines, oxidative stress was observed on HepG2 and TK6 (Table 4) cells exposed for $1.5 \mathrm{~h}$ to PTMC- $b-\mathrm{PGA}$ with a value of $4.29 \pm 0.44$-fold for HepG2 and $2.01 \pm 0.05$-fold for TK6 over their respective controls $(1.05 \pm 0.21$ and $1.30 \pm 0.60)$. Further testing of PTMC- $b-$ PGA in these two cell lines at lower concentrations indicated a dose-response effect in TK6 and HepG2 (data not shown). PEG- $b$-PBLG did not exert any rise in oxidative stress in all cell lines tested as shown in Table 4.
Cytokine production determination

The cytokine release triggered by the different cell lines after incubation with both NPs is shown in Fig. 7. IL-1, TNF $\alpha$, IL- 6 and IL- 8 were studied by ELISA. All ILs showed a similar pattern. There was no statistically significant difference between the amounts of cytokine levels in all cell lines after exposure with PEG- $b-$ PBLG. Regarding PTMC- $b-$ PGA, a similar effect was observed, except for A459 cell line. In this lung-derived cell line, a statistically significant increase of cytokines was noticed for the PTMC- $b$-PGA treated group with respect to the untreated control group (161.5 $\pm 30.8 \%$ increase in IL-1, a $151.0 \pm 43.9 \%$ increase in TNF $\alpha, 170.1 \pm$ $28.3 \%$ increase in IL-6 and $171 \pm 25.1 \%$ increase in IL-8 with respect to control group cytokines values $100 \pm 30$ ). 
Fig. 5 Percentage of Annexin V (a) and propidium iodide

(b) positive cells analyzed by flow cytometry after $72 \mathrm{~h}$ of NPs exposure. Values are expressed as the mean of \% positive cells $\pm \mathrm{SD}$. Onefactor analysis of variance (ANOVA) was performed

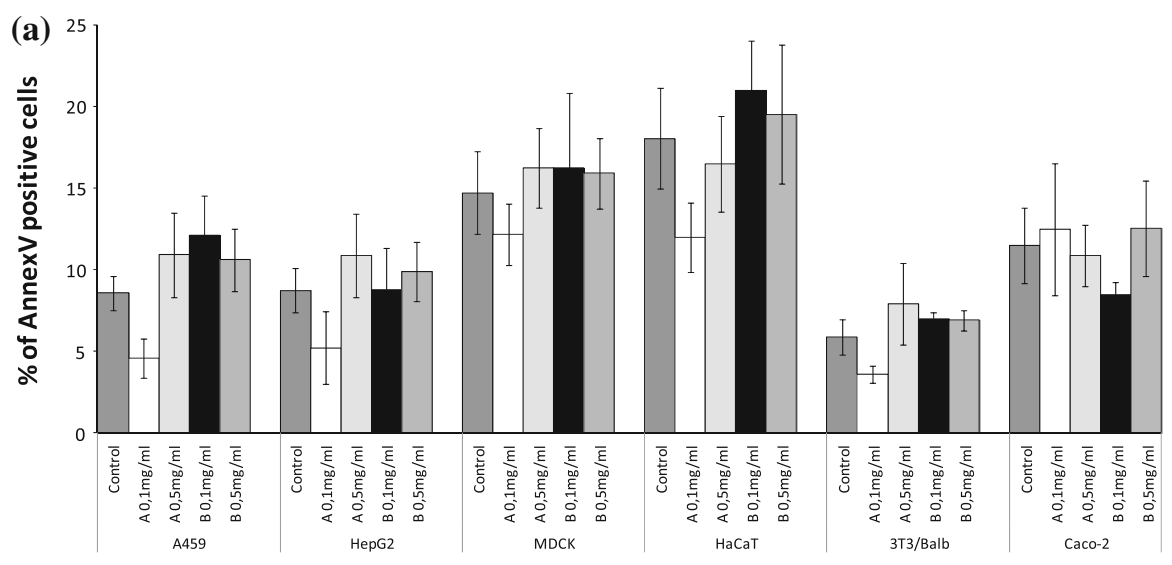

Experimental groups

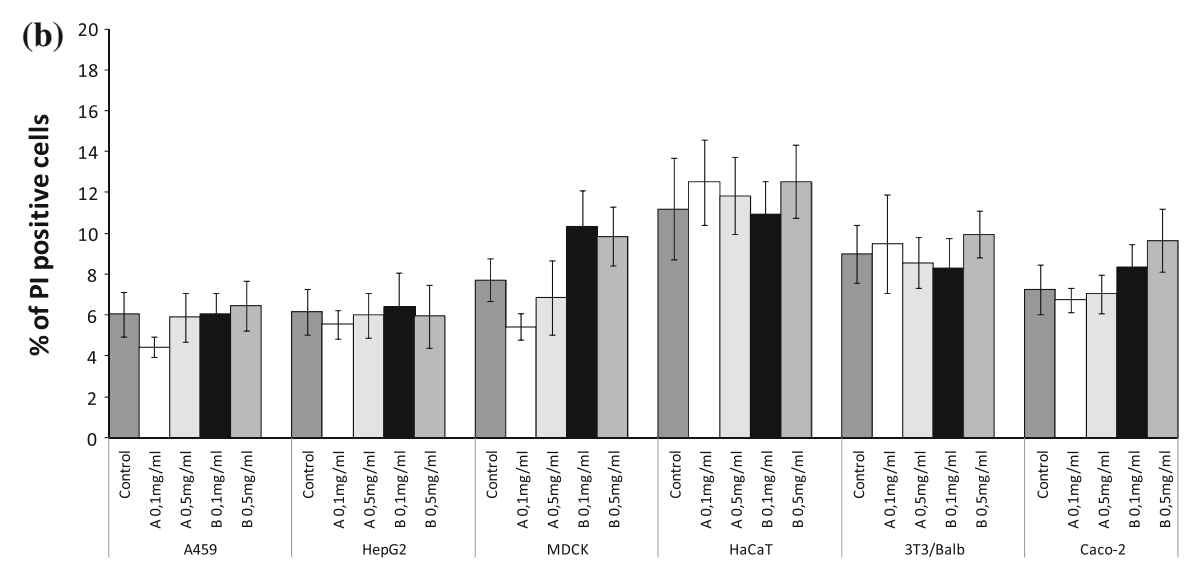

Experimental groups

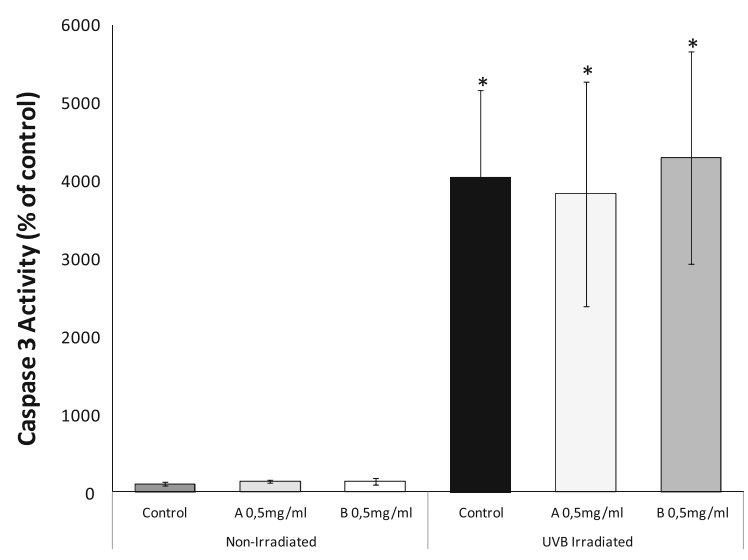

Fig. 6 Apoptosis induction analysis using PTMC- $b-$ PGA and PEG- $b-$ PBLG at $0.5 \mathrm{mg} / \mathrm{ml}$ before (non-irradiated) and after irradiation with UVB light (UVB irradiated) based on caspase 3 assay. Values are expressed as the mean of $\%$ positive cells \pm SD. One-factor analysis of variance (ANOVA) was performed. $* p<0.005$ respect to control culture
Table 4 Relative changes in oxidative stress induced by the exposure of different cell culture to $0.5 \mathrm{mg} / \mathrm{ml}$ of PTMC- $b$ PGA or PEG- $b-$ PBLG

\begin{tabular}{llll}
\hline & Control & PTMC- $b-$ PGA & PEG- $b-$ PBLG \\
\hline A549 & $1.28 \pm 0.30$ & $1.25 \pm 0.07$ & $1.05 \pm 0.04$ \\
HepG2 & $1.05 \pm 0.21$ & $4.50 \pm 0.44^{*}$ & $1.05 \pm 0.03$ \\
MDCK & $0.96 \pm 0.24$ & $0.84 \pm 0.03$ & $0.92 \pm 0.09$ \\
HaCaT & $1.04 \pm 0.13$ & $1.03 \pm 0.08$ & $1.02 \pm 0.07$ \\
BALB/3T3 & $1.06 \pm 0.37$ & $1.03 \pm 0.22$ & $1.09 \pm 0.14$ \\
Caco-2 & $1.02 \pm 0.09$ & $1.15 \pm 0.02$ & $1.00 \pm 0.03$ \\
TK6 & $1.30 \pm 0.60$ & $2.62 \pm 0.05^{*}$ & $1.00 \pm 0.03$ \\
\hline
\end{tabular}

Results based on FACS analysis are expressed as $G$ mean/ control $\pm \mathrm{SD}$

$* p<0.005$ respect to control culture 

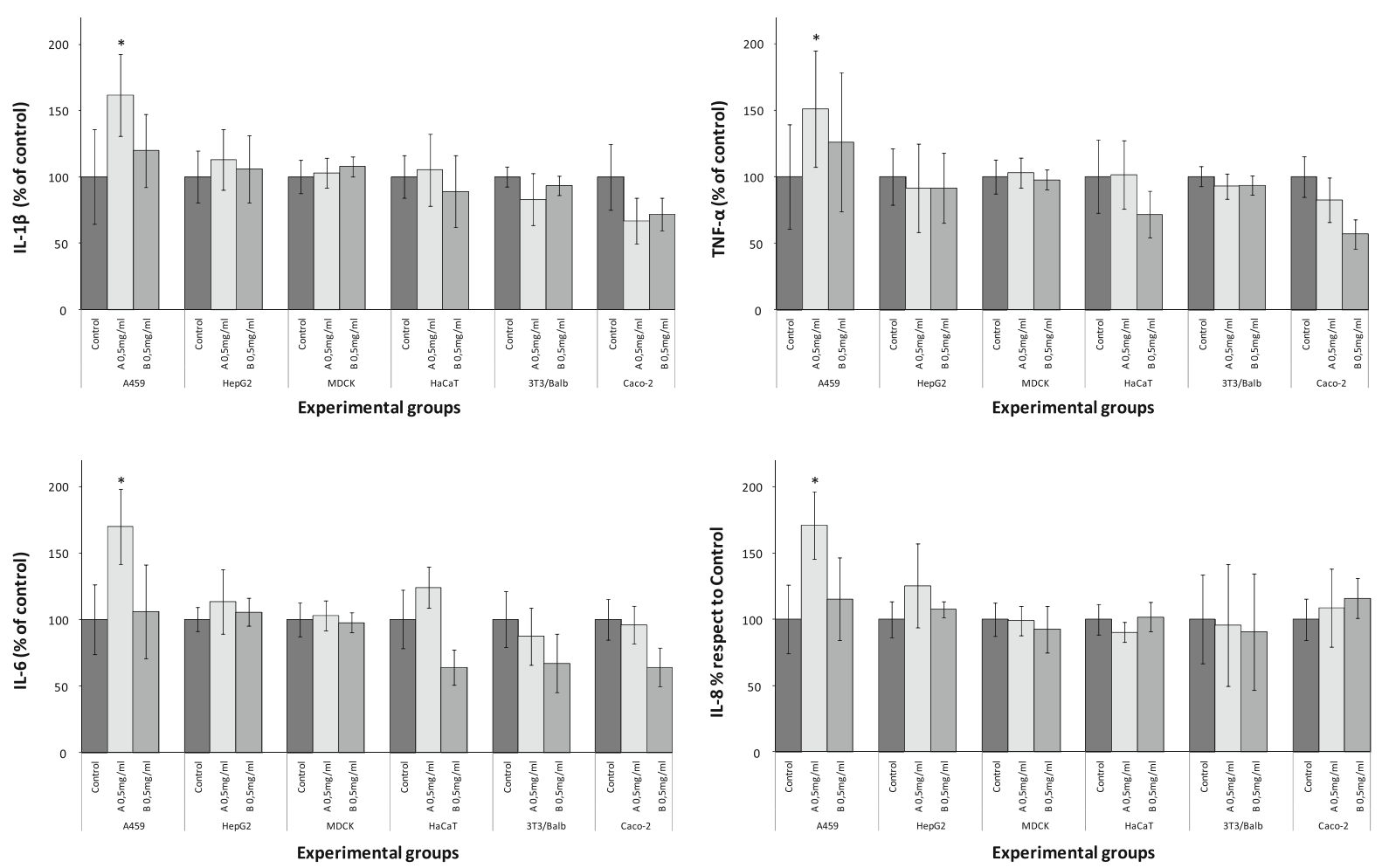

Fig. 7 Cytokine induction of TNF $\alpha$ (top left), IL-1 (top right), IL-6 (bottom left) and IL-8 (bottom right) analysis performed by ELISA technique after $24 \mathrm{~h}$ of incubation of A549, HepG2, MDCK, HaCaT, BALB/3T3 and Caco- 2 cell lines as test system

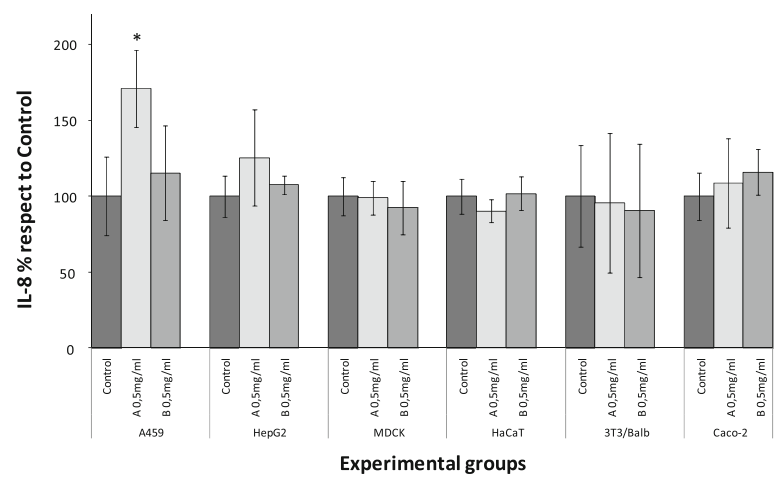

with $0.5 \mathrm{mg} / \mathrm{ml}$ of PTMC- $b$-PGA or PEG- $b$-PBLG. One-factor analysis of variance (ANOVA) was performed. $* p<0.005$ respect to control culture

Fig. 8 Skin model HSOC cytokine production assays by TNF $\alpha$, IL-1, IL- 6 and IL8 detection before (nonirradiated) and after irradiation with UVB light (UVB irradiated) at $24 \mathrm{~h}$ after incubation with $0.5 \mathrm{mg} / \mathrm{ml}$ of PTMC- $b-$ PGA or PEG- $b-\mathrm{PBLG}$. One-factor analysis of variance (ANOVA) was performed. $* p<0.005$ respect to non-irradiated control. ${ }^{\#} p<0.005$ respect to UVB irradiated control

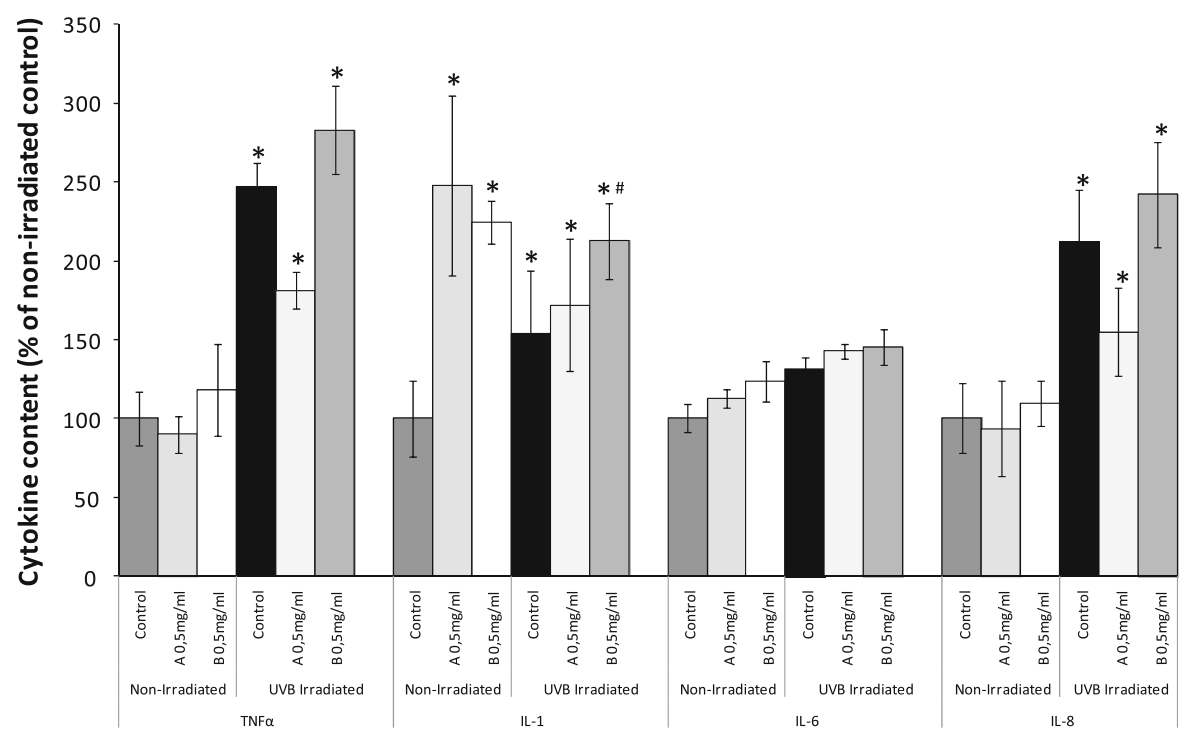

Cytokine production analysis in HSOC model after $24 \mathrm{~h}$ incubation with the different NPs is shown in Fig. 8. Results from non irradiated samples showed that cytokine levels were similar after $24 \mathrm{~h}$ exposure to NPs when compared to unexposed control samples. Furthermore, a statistically significant increase in IL-1 
values for both PTMC- $b$-PGA and PEG- $b-$ PBLG NPs treatments in relation to unexposed control (248.01 \pm $56.9,224.73 \pm 33.6$ and $100 \pm 24.2 \%$, respectively) was also observed.

Regarding UVB irradiation, every studied cytokine level showed an increase in all UVB irradiated groups with respect to non-irradiated control. TNF $\alpha$ and IL-8 levels showed a statistically significant increase in all the irradiated untreated and PTMC- $b$-PGA and PEG$b$-PBLG treated groups compared to non-irradiated control group. Likewise, all irradiated groups presented an increase in IL-6 levels in comparison to nonirradiated samples, but this increment was not statistically significant. Anyway, for TNF $\alpha$, IL-6 and IL-8, there were no statistically significant differences in the irradiated NPs treated samples according to UVB irradiated control samples. However, comparing the IL-1 values of PEG- $b$-PBLG treated UVB irradiated samples $(212.5 \pm 40.1 \%)$ and UVB irradiated control $(153.7 \pm 30 \%)$, a significant increase was observed. This effect could not be seen for the PTMC- $b-$ PGA treated and UVB irradiated samples.

\section{Discussion}

PTMC- $b-$ PGA and PEG- $b-$ PBLG NPs have been described as promising nanocarriers for therapy and/or diagnosis (Sanson et al. 2010a; Li 2002; Jeong et al. 2005). Previous studies demonstrated the dispersion stability of these carriers in water. However, in order to allow the in vitro toxicity testing and to assess their suitability as nanocarriers, it is crucial to determine their behaviour in physiological conditions (i.e. cell culture media or blood serum). According to the results obtained, NPs synthesis and characterisation rendered two different NPs with different nature and behaviour. PTMC- $b-$ PGA NPs show a vesicular morphology with DLS parameters similar to those already described in Sanson et al. (2010a). A particulate morphology was obtained with PEG- $b$-PBLG, with hydrodynamic sizes similar to those indicated in Martinez Barbosa et al. (2007). This different nature may actually generate different toxicological behaviour.

According to Fig. 1, it is important to note that these two NPs have a rather homogeneous size distribution in water, with a PDI below 0.2 for both PEG- $b-$ PBLG and PTMC- $b-$ PGA. The DLS analyses in MEM supplemented with $10 \%$ serum showed an increase of the PDI value for both NPs. This higher PDI (as compared to the measure in water or MEM with $1 \%$ or less serum) could be explained by the presence of a higher concentration of proteins which-although they are less diffusive than the particles-interfere with the measurement, rendering the dispersion less monodisperse (two populations with very different characteristic sizes: the particles around $100 \mathrm{~nm}$ and the serum proteins, less than $10 \mathrm{~nm}$ ). This hypothesis is supported by the fact that the mean hydrodynamic diameters did not significantly increase with the serum content (which would have been a sign of particles aggregation). As a result of the measurements and keeping into account the considerations for both PTMC- $b$-PGA and PEG- $b-$ PBLG, they display substantial stability in MEM cell culture medium.

Furthermore, the precipitated protein amount associate to both NPs was very low compared to the total amount of protein present in blood serum, indicating low or no interaction between NPs and proteins. Both NPs have a polymeric nature, with an amphiphilic character of the copolymers they are composed of. They are small with less than $150 \mathrm{~nm}$ in diameter and are likely to be transported through the bloodstream by transporter proteins like apolipoproteins or albumins. These NPs may be "coated" by proteins to form a protein-NP complex to be easily transported through the bloodstream. This needs further research in terms of pharmacokinetics and distribution which needs to be done in vivo. In the case of PTMC- $b$-PGA, the proteins identified belong in metabolic routes like lipid transport, antigen presentation and inflammatory response. These last two metabolic routes could be related to the toxicological effect of this NP and may indicate a slight immunogenic character of PTMC- $b-$ PGA.

To date, there is a lack of consensus in the published literature on NP in vitro toxicity mainly due to variability of methodology and cell lines. Traditionally, in vitro toxicity testing focuses on whether the exposure or not to a potentially toxic agent results in cell death. The majority of NP in vitro cytotoxicity assays published measure cell death via colorimetric methods. The most widely used test is the MTT viability assay (Chen et al. 2011; Tang et al. 2011; Yang et al. 2010; Tian et al. 2006). In the present study we have taken into account that NPs could interfere 
with dyes and dye products in viability assays through the adsorption of cell medium constituents (Zhang et al. 2007; Monteiro-Riviere et al. 2009). We tried to overcome this by carrying out two different tests; $\mathrm{AB}$ assays that determine the activity of a mitochondrial enzyme and are commonly used to determine the proliferative activity of cells by colorimetry or fluorescence, and CFE assay that indicates cell proliferation without the use of any cellular dye (Ponti et al. 2010) to discover possible false positives observed by $\mathrm{AB}$ assay. Both $\mathrm{AB}$ and $\mathrm{CFE}$ assays showed a nontoxic pattern (at cellular level) of PEG- $b$-PBLG and PTMC- $b-\mathrm{PGA}$ at 24 and $72 \mathrm{~h}$. Although no cell death may be apparent after NP exposure, changes in cellular function may result. So, sub-lethal cellular changes have also been assessed after NPs exposure on apoptosis induction like ROS production and cytokines release to ensure that valid conclusions were drawn.

Likewise, the systemic effects of some nanocompounds have been shown in different tissues and organs such as lung, intestine, skin, kidney and liver (Buzea et al. 2007). NPs properties such as size, surface chemistry, chemical composition or dosage may pose a threat to human health (Ai et al. 2011). So, cell lines representing these potential target organs were used to observe cytotoxicity, ROS production or pro-inflammatory cytotoxic activity that may occur as a result of the effects of PEG- $b-$ PBLG and PTMC- $b$ PGA NPs (Geiser and Kreyling 2010; Medina et al. 2007; Revell 2006). In order to increase the complexity of the experimental system to get closer to an in vivo situation, HSOC model was used to further test the toxicity of these NPs.

As described above, some researchers expressed limited confidence in colorimetric cytotoxicity methods due to shortcomings in sensitivity and specificity (Monteiro-Riviere et al. 2009). This is the reason why other methods, like cell membrane asymmetry studies, have been employed. Thus, using Annexin $\mathrm{V}$, our study indicates that no increase in necrosis and apoptosis index is detected in the employed cell cultures incubated with both PEG- $b-\mathrm{PBLG}$ and PTMC- $b$-PGA NPs. HSOC model showed an apoptosis induction due to UVB irradiation, but it seems to be independent of the NPs treatments performed.

ROS is a natural byproduct of the normal metabolism of oxygen and has important roles in cell signalling and homeostasis (Matsuzawa et al. 2005). These ROS at high concentrations have damaging effects upon cell viability and function, and in turn, stimulate innate immune responses (Tomoda et al. 2012). According to our flow cytometry analysis, oxidative stress assays showed no effect in most of the cell lines tested. Only HepG2 and TK6 showed statistical significant increase in ROS formation after treatment with PTMC- $b$-PGA NP. Moreover, this effect was dose-dependent for these cell lines (data not shown).

Oxygen species formation is the most common effect generated by NPs like fullerenes, carbon nanotubes, quantum dots, etc. (Raab et al. 2008; Oberdörster et al. 2005). Due to the larger surface area to mass ratio of smaller particles, more ROS could be formed than in treatments with larger particles (Sioutas et al. 2005; Stone et al. 2000). This is not the case as both NPs have a similar size and shape, so this effect is probably due to the different nature of the NPs. The biggest difference between both NP is their $\zeta$, which was -9 and $-42 \mathrm{mV}$ for PEG- $b-$ PBLG and PTMC- $b-$ PGA, respectively in water. Moreover, when comparing the effect of PTMC- $b$-PGA over the whole set of cell lines used in this study, it seems evident that all cells types did not have the same sensitivity to ROS formation. The most sensitive cell line seems to be the hepatocarcinoma derived HepG2, followed by TK6 cell line, a human lymphoblast derived cell line. Liver cells interact with xenobiotics and foreign bodies to eliminate them and avoid the possible toxic effects they may cause. Furthermore, hepatocytes take up large amounts of different molecules from plasma for oxidation and synthesis (Guo et al. 2006). It might be possible that HepG2 cells uptake this NP with high affinity and thus, generate higher levels of ROS. Lymphocytes, as part of immune system, also interact with foreign substances, to trigger immune response, so this might also be a reason why these cells seem to be more sensitive to ROS formation. It is also interesting to note that according to the results obtained in the blood-serum interaction assays, antigen presentation is one of the cellular routes associated to this NP, supporting the idea of a rather immunogenic nature of PTMC- $b$-PGA. Anyway, this hypothesis need further checking and more assays need to be done regarding this issue.

Cytokine production is also a possible adverse effect upon NP exposure to cells. In this study, 
commonly tested pro-inflammatory cytokines (IL-1 $\beta$, IL-6, IL-8 and TNF $\alpha$ ) were analyzed (Dinarello 2000; Schanen et al. 2009). Results from cytokine production experiments showed that cytokine levels were similar after $24 \mathrm{~h}$ in cells exposed to PEG- $b-$ PBLG NPs. However, the cytokine level values in A549 cell line exposed to PTMC- $b$-PGA NPs after $24 \mathrm{~h}$ suffered a statistically significant increase. The A549 cell line is derived from lung epithelium. Air pollutants and other substances, like sulphur dioxide, are known to trigger inflammatory response in this cell line (Backand et al. 2011). In vitro and in vivo studies support the idea that NPs in general are significant contributors to pulmonary fibrosis (Oberdörster 2000). The differential behaviour in cytokine production of these two NPs might be attributed again to differences in $\zeta$. A marked negative $\zeta$ has a direct relationship in cytokine production compared the low effect of a neutral or positive charged NP (Yost et al. 2006).

Regarding to HSOC model, it has been published as a recognized model to study ROS, cytokine production and structural alteration associated to UVB generated damage (Portugal-Cohen et al. 2011). In PortugalCohen's study, inflammatory cytokines were drastically increased after UVB irradiation, a similar effect observed in this study. NPs addition and further UVB irradiation did not change that inflammatory profile, indicating a low inflammatory effect of PEG- $b-$ PBLG and PTMC- $b$-PGA NPs both in non-irradiated and UVB irradiated human skin explants. However, IL-1 values showed a significant increase after PEG- $b-$ PBLG NPs incubation. IL-1 is produced by multiple types of cells, including immune system cells and epithelial cells and, in particular, this IL is related to caspase protein family, involved in apoptosis (Svobodova et al. 2006).

Our results suggest that the main damage occurred to HSOC model should be allocated to UVB light, but the use of PEG- $b$-PBLG enhances that damage, indicating that this NP might not be a good choice as a vehicle for dermatological applications.

\section{Conclusions}

The aim of this thorough study was to ascertain whether PTMC- $b$-PGA and PEG- $b-$ PBLG could potentially be good candidates for drug delivery based on a low toxicity profile. Our results indicate that these two NPs hardly interact with human blood serum suggesting that both nanosystems could be potential candidates for systemic drug delivery. In vitro cytotoxicity is very low and only ROS formation can be considered as a toxicity mechanism of action for one of the NPs in two out of the seven cell lines tested. The values for cytokine production in cell lines are only slightly high in the lung epithelial cell line, indicating that inhalation route may represent a problem to overcome if using PTMC- $b-$ PGA as nanocarrier. Likewise, according to human skin explants results for PEG- $b-\mathrm{PBLG}$, this might not be the best system to be used for dermatological applications.

In general, these two NPs could be good candidates for drug delivery systems, but further in vitro and in vivo studies must be performed in order to have a clearer and more accurate view of the potential use of these polymeric nanosystems.

Acknowledgments This study was supported by the European Commission FP7 Programme 2007-2013 under NANOTHER project (www.nanother.eu), Grant Agreement Number CP-IP 213631-2 NANOTHER. We want to particularly acknowledge the patients enrolled in the blood serum study for their participation and the Basque Biobank for Research-OEHUN for its collaboration.

\section{References}

Ai J, Biazar E, Jafarpour M, Montazeri M, Majdi A, Aminifard S, Zafari M, Akbari HR, Rad HG (2011) Nanotoxicology and nanoparticle safety in biomedical designs. Int J Nanomed 6:1117-1127

Arimura H, Ohya Y, Ouchi T (2005) Formation of core-shell type biodegradable polymeric micelles from amphiphilic poly(aspartic acid)-block-polylactide diblock copolymer. Biomacromolecules 6(2):720-725

Backand S, Winder C, Hayes A (2011) Cell viability and cytokine production of human alveolar epithelial cells following exposure to sulphur dioxide. Int J Occup Hyg 3:63-69

Buzea C, Pacheco-Blandino II, Robbie K (2007) Nanomaterials and nanoparticles: sources and toxicity. Biointerphases 2:MR17-MR172

Carlsen A, Lecommandoux S (2009) Self-assembly of polypeptide-based block copolymer amphiphiles. Curr Opin Colloid Interface Sci 14(5):329-339

Chen Y, Wan Y, Wang Y, Zhang H, Jiao Z (2011) Anticancer efficacy enhancement and attenuation of side effects of doxorubicin with titanium dioxide NPs. Int J Nanomed 6:2321-2326 
Chiellini EE, Chiellini F, Solaro R (2006) Bioerodible polymeric NPs for targeted delivery of proteic drugs. J Nanosci Nanotechnol 6(9-10):3040-3047

Chiellini F, Bartoli C, Dinucci D, Piras AM, Anderson R, Croucher T (2007) Bioeliminable polymeric NPs for proteic drug delivery. Int J Pharm 343(1-2):90-97

Curtis J, Greenberg M, Kester J, Phillips S, Krieger G (2006) Nanotechnology and nanotoxicology: a primer for clinicians. Toxicol Sci 25(4):245-260

Dinarello CA (2000) Proinflammatory cytokines. Chest 118:503-508

Dong AJ, Deng LD, Sun DX, Zhang YT, Jin JZ, Yuan YJ (2004) Studies on paclitaxel-loaded NPs of amphiphilic block copolymer. Yao Xue Xue Bao 39(2):149-152

Duncan R, Ringsdorf H, Satchi-Fainaro R (2006) Polymer therapeutics I. In: Advances in polymer science. Springer, Berlin, pp 1-8

Geiser M, Kreyling WG (2010) Deposition and biokinetics of inhaled nanoparticles. Part Fibre Toxicol 7(2). doi:10. 1186/1743-8977-7-2

Guo W, Huang N, Cai J, Xie W, Hamilton JA (2006) Fatty acid transport and metabolism in HepG2 cells. Am J Physiol Gastrointest Liver Physiol 290:528-534

Jeong YI, Nah JW, Lee HC, Kim SH, Cho CS (1999) Adriamycin release from flower-type polymeric micelle based on star-block copolymer composed of poly (gamma-benzyl L-glutamate) as the hydrophobic part and poly(ethylene oxide) as the hydrophilic part. Int J Pharm 188(1):49-58

Jeong YI, Kang MK, Sun HS, Kang SS, Kim HW, Moon KS, Lee KJ, Kim SH, Jung S (2004) All-trans-retinoic acid release from core-shell type NPs of poly(epsilon-caprolactone)/poly(ethylene glycol) diblock copolymer. Int J Pharm 273(1-2):95-107

Jeong YI, Seo SJ, Park IK, Lee HC, Kang IC, Akaike T, Cho CS (2005) Cellular recognition of paclitaxel-loaded polymeric NPs composed of poly(gamma-benzyl L-glutamate) and poly(ethylene glycol) diblock copolymer endcapped with galactose moiety. Int J Pharm 296(1-2):151-161

Kricheldorf H (2006) Polypeptides and 100 years of chemistry of alpha-amino acid $\mathrm{N}$-carboxyanhydrides. Angew Chem Int Ed Engl 45(35):5752-5784

Lankelma J, Dekker H, Luque FR, Luykx S, Hoekman K, Van der Valk P (1999) Doxorubicin gradients in human breast cancer. Clin Cancer Res 5:1703-1707

Lanone S, Boczkowski J (2006) Biomedical applications and potential health risks of nanomaterials: molecular mechanisms. Curr Mol Med 6(6):651-663

Li C (2002) Poly(L-glutamic acid)-anticancer drug conjugates. Adv Drug Deliv Rev 54(5):695-713

Li S, Wang A, Jiang W, Guan Z (2008) Pharmacokinetic characteristics and anticancer effects of 5-fluorouracil loaded NPs. BMC Cancer 8:103-111

Li X, Wang L, Fan Y, Feng Q, Cui F (2012) Biocompatibility and toxicity of NPs and nanotubes. J Nanomater 2012, Article ID 548389. doi:10.1155/2012/548389

Mandal D, Chatterjee U (2007) Synthesis and spectroscopy of CdS NPs in amphiphilic diblock copolymer micelles. J Chem Phys 126(13):13450-13457

Martinez Barbosa ME, Montembault V, Cammas-Marion S, Ponchel G, Fontaine L (2007) Synthesis and characterization of novel poly( $\gamma$-benzyl-L-glutamate) derivatives tailored for the preparation of NPs of pharmaceutical interest. Polym Int 56:317-324

Matsuzawa A, Saegusa K, Noguchi T, Sadamitsu C, Nishitoh H, Nagai S, Koyasu S, Matsumoto K, Takeda K, Ichijo H (2005) ROS dependent activation of the TRAF6-ASK1p38 pathway is selectively required for TLR4-mediated innate immunity. Nat Immunol 6:587-592

Medina C, Santos-Martinez MJ, Radomski A (2007) Nanoparticles: pharmacological and toxicological significance. $\mathrm{Br} \mathrm{J}$ Pharmacol 150:552-558

Monteiro-Riviere NA, Inman AO, Zhang LW (2009) Limitations and relative utility of screening assays to assess engineered NP toxicity in a human cell line. Toxicol Appl Pharmacol 234:222-235

Nishiyama N, Kataoka K (2006) Polymer therapeutics II. In: Advances in polymer science. Springer, Berlin, pp 67-101

Oberdörster G (2000) Toxicology of ultrafine particles: in vivo studies. Philos Trans R Soc Lond A 358:2719-2740

Oberdörster G, Oberdörster E, Oberdörster J (2005) Nanotoxicology: an emerging discipline evolving from studies of ultrafine particles. Environ Health Perspect 113(7):823-839

Oh I, Lee K, Kwon HY, Lee YB, Shin SC, Cho CS, Kim CK (1999) Release of adriamycin from poly (gamma-benzyl-Lglutamate)/poly(ethylene oxide) NPs. Int J Pharm 181(1): 107-115

Ponti J, Colognato R, Rauscher H, Gioria S, Broggi F, Franchin F, Pascual C, Giudetti G, Rossi F (2010) Colony forming efficiency and microscopy analysis of multi-wall carbon nanotubes cell interaction. Toxicol Lett 197:29-37

Portugal-Cohen M, Soroka Y, Frušić-Zlotkin M, Verkhovsky L, Brégégère FM, Neuman R, Kohen R, Milner Y (2011) Skin organ culture as a model to study oxidative stress, inflammation and structural alterations associated with UVB-induced photodamage. Exp Dermatol 20(9):749-755

Raab C, Simkó M, Gazsó A, Fiedeler U, Nentwich M (2008) Was sind synthetische Nanopartikel?. NanoTrust-Dossiers Nr. 002, hg. v. Institut für Technikfolgen-Abschätzung, Wien

Revell PA (2006) The biological effects of nanoparticles. Nanotechnol Percept 2:283-298

Sanson C, Schatz C, Le Meins JF, Brulet A, Soum A, Lecommandoux S (2010a) Biocompatible and biodegradable poly(trimethylene carbonate)- $b$-poly(L-glutamic acid) polymersomes: size control and stability. Langmuir 26(4): 2751-2760

Sanson C, Schatz C, Le Meins JF, Soum A, Thévenot J, Garanger E, Lecommandoux $S$ (2010b) A simple method to achieve high doxorubicin loading in biodegradable polymersomes. J Control Release 147:428-435

Sanson C, Diou O, Thevenot J, Ibarboure E, Soum A, Brûlet A, Miraux S, Thiaudière E, Tan S, Brisson A, Dupuis V, Sandre O, Lecommandoux S (2011) Doxorubicin loaded magnetic polymersomes: theranostic nanocarriers for MR imaging and magneto-chemotherapy. ACS Nano 5:11221140

Satchi-Fainaro R, Duncan R, Barnes C (2006) Polymer therapeutics II. In: Advances in polymer science. Springer, Berlin, pp 1-65

Schanen BC, Karakoti AS, Seal S, Drake DR, Warren WL, Self WT (2009) Exposure to titanium dioxide nanomaterials provokes inflammation of an in vitro human immune construct. ACS Nano 3:2523-2532 
Sioutas C, Delfino RJ, Singh M (2005) Exposure assessment for atmospheric ultrafine particles (UFPs) and implications in epidemiologic research. Environ Health Perspect 113(8): 947-955

Stone V, Tuinman M, Vamvakopoulos JE, Shaw J, Brown D, Petterson S, Faux SP, Borm P, MacNee W, Michaelangeli F, Donaldson K (2000) Increased calcium influx in a monocytic cell line on exposure to ultrafine carbon black. Eur Respir J 15(2):297-303

Svobodova A, Walterova D, Vostalova J (2006) Ultraviolet light induced alteration to the skin. Biomed Pap Med Fac Univ Palacky Olomouc Czech Repub 150(1):25-38

Tang H, Guo J, Sun Y, Chang B, Ren Q, Yang W (2011) Facile synthesis of $\mathrm{pH}$ sensitive polymer-coated mesoporous silica NPs and their application in drug delivery. Int J Pharm 421:388-396

Tian F, Cui D, Schwarz H, Estrada GG, Kobayashi H (2006) Cytotoxicity of single-wall carbon nanotubes on human fibroblasts. Toxicol In Vitro 20:1202-1212

Tomoda K, Watanabe A, Suzuki K, Inagi T, Terada H, Makino K (2012) Enhanced transdermal permeability of estradiol using combination of PLGA nanoparticles system and iontophoresis. Colloids Surf B 97:84-89

Upadhyay KK, Agrawal HG, Upadhyay C, Schatz C, Le Meins JF, Misra A, Lecommandoux S (2009) Role of block copolymer nanoconstructs in cancer therapy. Crit Rev Ther Drug Carr Syst 26(2):157-205

Vega-Villa KR, Takemoto JK, Yáñez JA, Remsberg CM, Forrest ML, Davies NM (2008) Clinical toxicities of nanocarrier systems. Adv Drug Deliv Rev 60:929-938

Yang Y, Qu Y, Lü X (2010) Global gene expression analysis of the effects of gold NPs on human dermal fibroblasts. J Biomed Nanotechnol 6:234-246

Yost GS, Veranth JM, Reilly CA, Veronesi B (2006) Chapter 8: vanilloid receptors in the respiratory tract. In: Gardner DE (ed) Toxicology of the lung, 4th edn. Taylor and Francis Group, Boca Raton, pp 297-350

Zhang LW, Zeng L, Barron AR, Monteiro-Riviere NA (2007) Biological interactions of functionalized single-wall carbon nanotubes in human epidermal keratinocytes. Int $\mathbf{J}$ Toxicol 26:103-113 